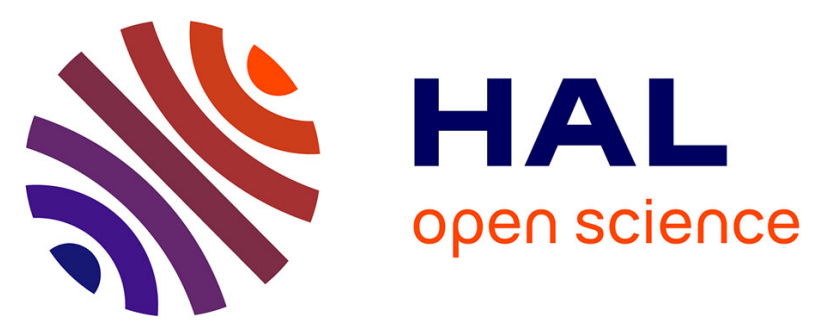

\title{
Litter inputs and plant interactions affect nectar sugar content
}

Mathilde Baude, Julie Leloup, Séverine Suchail, Béatrice Allard, Danielle

Benest, Jacques Meriguet, Naoise Nunan, Isabelle Dajoz, Xavier Raynaud

\section{- To cite this version:}

Mathilde Baude, Julie Leloup, Séverine Suchail, Béatrice Allard, Danielle Benest, et al.. Litter inputs and plant interactions affect nectar sugar content. Journal of Ecology, 2011, 99 (3), pp.828-837. 10.1111/j.1365-2745.2011.01793.x . hal-02047775

\section{HAL Id: hal-02047775}

\section{https://hal-univ-avignon.archives-ouvertes.fr/hal-02047775}

Submitted on 25 Feb 2019

HAL is a multi-disciplinary open access archive for the deposit and dissemination of scientific research documents, whether they are published or not. The documents may come from teaching and research institutions in France or abroad, or from public or private research centers.
L'archive ouverte pluridisciplinaire HAL, est destinée au dépôt et à la diffusion de documents scientifiques de niveau recherche, publiés ou non, émanant des établissements d'enseignement et de recherche français ou étrangers, des laboratoires publics ou privés. 


\title{
Litter inputs and plant interactions affect nectar sugar content
}

\author{
Mathilde Baude ${ }^{1,2 *}$, Julie Leloup ${ }^{1}$, Séverine Suchail ${ }^{3}$, Béatrice Allard ${ }^{4}$, Danielle Benest ${ }^{4}$, \\ Jacques Mériguet ${ }^{5}$, Naoise Nunan ${ }^{4}$, Isabelle Dajoz ${ }^{2}$ and Xavier Raynaud ${ }^{1}$ \\ ${ }^{1}$ UPMC-Paris 6, UMR 7618, Bioemco, F-75005 Paris, France; ${ }^{2}$ Université Paris Diderot-7, UMR 7618, Bioemco, \\ F-75005 Paris, France; ${ }^{3}$ Université d'Avignon et des Pays de Vaucluse, UMR 406 Abeilles et Environnement Site \\ Agroparc, F-84914 Avignon, France; ${ }^{4}$ CNRS, UMR 7618, Bioemco, F-75005 Paris, France; ${ }^{5}$ ENS, UMR 7618, \\ Bioemco, F-75005 Paris, France
}

\section{Summary}

1. Declines in availability of plant resources to pollinators are a major cause of pollinator loss. The management of plant communities to enhance floral resources is often proposed as a way to sustain pollinator populations. Nectar, the main energetic resource for pollinators, plays a central role in behaviour and composition of pollinator communities. Abiotic and biotic factors are known to influence nectar traits at both the species and community levels, but the impact of plant community composition itself has never been investigated.

2. Below-ground interactions in plant communities can induce changes in plant development through (i) plant-derived litter amendment of the soil and (ii) competition for soil resources between plants. We tested how plant below-ground interactions affect above-ground nectar traits involved in plant attractiveness to pollinators.

3. A short-term pot experiment was carried out with three temperate grassland species Mimulus guttatus, Lamium amplexicaule, and Medicago sativa, showing distinct litter stoichiometry and competitive abilities for soil resources. Litter amendment (none, mono and tri-specific litter) and plant interaction treatments (monocultures, two- and three-species mixtures) were crossed in a factorial design.

4. Litter amendment to the soil led to an increase in total nectar sugar content in L. amplexicaule plants but not in the two other species. We also found that the presence of M. guttatus, a competitive species, reduced the total nectar sugar content in L. amplexicaule through a concomitant decrease in nectar volume per flower and in floral display size, but not in other species. Species-specific responses of nectar traits to variation in soil nitrogen availability were thus observed, suggesting consequences for plant species and community attractiveness to pollinators. However, we did not find evidence that the legume $M$. sativa affected nectar traits of any neighbouring plants.

5. Synthesis. Our results demonstrate that litter inputs and competition between plants for soil resources can alter nectar traits linked to plant attractiveness to pollinators. This supports the idea that below-ground plant-plant interactions for soil resources can influence above-ground plantplant interactions for pollination services. This offers promising perspectives in studying the role of below-ground-above-ground interactions on higher trophic levels.

Key-words: above-ground-below-ground interactions, attractiveness, competition, diversity, floral display, nectar, plant-plant interactions, plant-pollinator interactions, plant-soil interactions

\section{Introduction}

A global pollination crisis has recently been recognized (AllenWardell et al. 1998; Steffan-Dewenter, Potts \& Packer 2005).

*Correspondence author. E-mail: mathilde.baude@ens.fr
Pollinators and services they provide are under increasing pressure from multiple perturbations of anthropogenic origin (Kearns, Inouye \& Waser 1998; Kremen \& Ricketts 2000). A decline in floral resources used by pollinators is considered to be one of the major causes involved in pollinator loss (Biesmeijer et al. 2006; Carvell et al. 2006; Potts et al. 2010). 
Nectar, which is mainly composed of sugars, provides energy required by active adult bees and other pollinating insects, whereas protein rich pollen is collected for larval growth (Proctor, Yeo \& Lack 1996). Pollen and nectar resources produced by flowers are therefore fundamental to sustaining pollinator populations. Conservation measures often promote the establishment of pollen and nectar-rich floral communities to preserve pollinator populations and enhance pollination services (Pywell et al. 2006; Carvell et al. 2007).

Nectar plays a key role in plant-pollinator systems as it influences pollinator behaviour (Klinkhamer \& de Jong 1990; Cresswell 1999; Klinkhamer, de Jong \& Linnebank 2001; Kudo \& Harder 2005) and pollinator community structure (Potts et al. 2003, 2004). Nectar is essentially an aqueous solution of sugars but also contains amino acids, proteins, lipids and a variety of secondary compounds (Dafni 1992). Among the glucidic fraction, three sugars are dominant: glucose, fructose (monosaccharides) and saccharose (a disaccharide of glucose and fructose). Nectar traits are highly variable among species (Wykes 1952; Percival 1961; Baker \& Baker 1979) and recent studies have also reported high intra-specific variability that occurs at several scales, from plant populations to nectaries (Lanza et al. 1995; Pierre et al. 1999; Herrera, Perez \& Alonso 2006). Nectar traits respond to biotic factors such as nectar sampling or herbivory (e.g. Castellanos, Wilson and Thomson 2002; Adler et al. 2006) as well as abiotic factors such as light, water, fertilization, temperature and $\mathrm{CO}_{2}$ concentration (e.g. Osborne et al. 1997; Rusterholz \& Erhardt 1998; Gardener \& Gillman 2001; Burkle \& Irwin 2009a). Indeed, soil nutrient availability to plants is known to influence the production of flowers (Muñoz et al. 2005; Burkle \& Irwin 2010), pollen (Lau \& Stephenson 1993) and nectar (Campbell \& Halama 1993; Gardener \& Gillman 2001; Burkle \& Irwin 2009a) and can lead to changes in subsequent pollinator visitation (Muñoz et al. 2005; Burkle \& Irwin 2010).

Studies on nectar traits have mostly been conducted at the species level and only few recent papers have considered the whole community (Burkle \& Irwin 2009b, 2010). In particular, the effects of plant community composition on individual nectar traits have never been explicitly studied, despite the fact that these individual traits contribute to community attractiveness to pollinators. In terrestrial communities, plant individuals interact with each other above-ground for light and belowground for water and nutrients. Because below-ground interactions between individuals affect plant nutrition, they might also affect floral and nectar traits. It can therefore be hypothesized that within plant communities, competitive species for soil resources should have a negative impact, whereas facilitative ones should have a positive impact on floral and nectar traits of neighbouring plants. Nutrient fluxes in soil result from nutrient uptake by plants and organic matter inputs from plants to the soil (Wardle et al. 2004). Some nutrients such as nitrogen are commonly derived from the decomposition of the litter of species present in the plant community. In nitrogenlimited ecosystems, positive effects of litter inputs to the soil on nectar traits of plants can be expected and the magnitude of this effect is likely to depend upon litter C:N stoichiometry (Trinsoutrot et al. 2000).

Here, we present a study aimed at investigating how belowground-above-ground interactions affect floral and nectar traits in plant communities. More precisely, we tested whether litter amendments and plant interactions within the community alter the traits involved in plant attractiveness to pollinators. A synthetic diagram of the main tested hypotheses is presented in Fig. 1. A short-term pot experiment was carried out using a complete factorial design in which three temperate grassland plants were grown in communities of one, two or three species with different types of litter amendment derived from the same plants (no litter, addition of litter from a single species or addition of a mix of litter of the three studied species). The plant species (Mimulus guttatus Fisch. ex DC., Lamium amplexicaule L. and Medicago sativa L.) were chosen because they can occur simultaneously in temperate grasslands, show distinct competitive abilities and have distinct litter stoichiometry.

\section{Materials and methods}

\section{EXPERIMENTAL TREATMENTS}

A pot experiment was set up based on different plant associations with different litter amendments in a complete factorial design. The 'plant interaction' treatment was induced by the manipulation of the assemblage of the three plant species in monocultures, two- and three-species mixtures (seven combinations in total). The 'litter' treatment consisted of five combinations of above-ground biomass of the

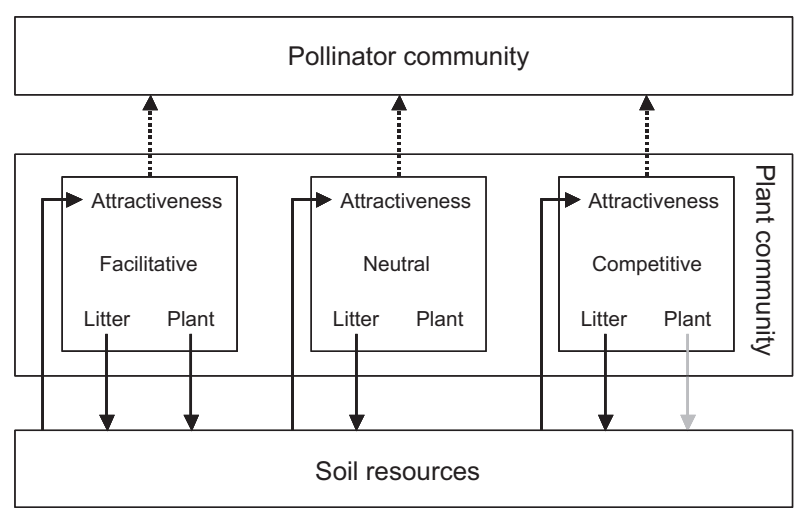

Fig. 1. Synthetic diagram of our experiment aimed at investigating how below-ground-above-ground interactions mediated through litter input ('Litter') and plant interaction ('Plant') affect plant traits involved in attractiveness to pollinators ('Attractiveness'). Large boxes represent soil resources, plant and pollinator communities. Black arrows indicate positive effects and grey arrows indicate negative ones. Solid arrows indicate tested effects in our experiment and dashed arrows represent extrapolated effect. A putative hierarchy of plants in their below-ground competitive abilities ('Facilitative', 'Neutral' and 'Competitive' species) composed plant communities. It was hypothesized that the availability of soil resources positively impacted plant traits linked to attractiveness to pollinators. Litter inputs and plant interaction with facilitative species should positively affect plant attractiveness to pollinators whereas plant interaction with competitive species should negatively affect plant attractiveness. 
same plant species: no litter, single species litters and three-species litter. The full factorial design thus comprised 35 combinations: seven plant associations $\times$ five litter inputs, in four replicates. This experimental design enabled us to test experimentally the effects of 'plant interaction' and 'litter' as well as the interaction between these factors on below-ground and above-ground parameters. Details on the choice of plant species, experimental set-up, measurements and statistical analyses are given below.

\section{PLANT SPECIES}

Three European grassland plant species were used: M. guttatus (MG, Scrophulariaceae), L. amplexicaule (LA, Lamiaceae) and M. sativa (MS, Fabaceae). These species were chosen among a pool of grassland plant species that are bee-pollinated and that can co-occur in natural situations since they share similar ecological requirements (Hill et al. 1999). The species also had to have flowers with easily accessible nectar to be suitable for the experiment.

Mimulus guttatus is a semi-perennial herb that occurs in semi-dry to wet grasslands. This species, native to North America, is invasive in some European countries. It exhibits strong competitive attributes including a short germination period, rapid growth and effective longand short-distance dispersal mechanisms (Truscott et al. 2006). It presents a mixed mating system with insect pollination and up to four modes of self-pollination. The main pollinators of M. guttatus are Apis mellifera, Bombus sp. and solitary bees (Robertson et al. 1999).

Lamium amplexicaule is an annual herb, native to Europe, that frequently occurs in grassland communities. Both cleistogamous (closed, autogamy) and chasmogamous (open, possible xenogamy) flowers are found on plants of L. amplexicaule (Lord 1978). Bombus $s p$. is the most important pollinator of this species (Proctor, Yeo \& Lack 1996).

Medicago sativa is a common perennial legume that frequently occurs in European grassland communities. Partial self-incompatibility is observed in M. sativa (Brink \& Cooper 1938). Pollinators of M. sativa are Bombus spp. and solitary bees, especially Megachilidae (Brookes et al. 1994). Due to their ability to fix $\mathrm{N}_{2}$, legumes are known to facilitate growth of non-N-fixing neighbouring plant species (Temperton et al. 2007). Therefore, the three species in our experiment belong to a putative competitive hierarchy for below-ground interactions, from the competitive $M$. guttatus to the facilitative species M. sativa.

\section{LITTERS}

Prior to the beginning of the experiment, litter was obtained by growing individuals of the three study species in optimal conditions. The above-ground biomass of each species was harvested, oven-dried $\left(65^{\circ} \mathrm{C}, 48 \mathrm{~h}\right.$ ), and ground to $0.08 \mathrm{~mm}$ (Retsch ZM 100, Fisher Bioblock Scientific, Illkirch, France). The resulting litter of M. guttatus, L. amplexicaule and M. sativa had C:N ratios of 13.95, 18.17 and 23.98 and C:P ratios of 9.01, 12.74 and 27.49, respectively. The threelitter mixture was obtained by mixing an equal ratio of each specific litter.

\section{EXPERIMENTAL SET-UP}

During the experiment, plants were grown in plastic pots $(14 \mathrm{~cm}$ diameter $\times 10.6 \mathrm{~cm}$ height; $1540 \mathrm{~cm}^{3}$ ) on a loamy sand soil. The soil was taken from depths of $5-20 \mathrm{~cm}$ in a grassland site near Paris (CEREEP Foljuif, Saint-Pierre-les-Nemours, Seine-et-Marne, France). The soil had a C:N ratio of 10.40 and a C:P ratio of
26.03. The soil was sieved $(<1 \mathrm{~cm})$ to remove rocks and large plant material.

The bottom of each pot was covered with a $118-\mu \mathrm{m}$ mesh and $10 \mathrm{~g}$ of vermiculite to prevent roots from growing out. Pots were then halffilled with a mixture of $600 \mathrm{~g}$ soil and $18 \mathrm{~g}$ vermiculite. Then $5.8 \mathrm{~g}$ of litter were incorporated into a second mixture of $500 \mathrm{~g}$ soil and $15 \mathrm{~g}$ vermiculite and added to the pots. The amount of litter that was added to the pots corresponded to an addition of $2.46 \mathrm{~g}$ of carbon, and c. $+30 \%$ C. This amount is approximately equivalent to the annual carbon deposit in natural grassland ecosystems $(0.16 \mathrm{~kg}$ $\mathrm{C} \mathrm{m}^{-2}$, Schlesinger 1997). Seeds of M. guttatus (MNHN, France), L. amplexicaule (Herbiseed, UK) and M. sativa (Herbiseed, UK) were germinated in Petri dishes, transplanted into experimental pots, and grown for 74 days. A substitutive design was adopted with a constant total number of six plants per pot $(6,3: 3,2: 2: 2$ plants of each species in monocultures, two- and three-species mixtures, respectively). In mixtures, different species were arranged in alternation. Artificial light conditions differed during the growth and flowering periods (growth period: Metal Halide $250 \mathrm{~W}$ Philips; flowering period: Sodium lighting $250 \mathrm{~W}$ Sylvania), with a 16 -h photoperiod. Pots were watered from below and their spatial position in the growth chamber was randomized throughout the experiment.

\section{TRAIT MEASUREMENTS}

In order to investigate the role of litter and plant interactions in determining above-ground traits linked to plant attractiveness to pollinators through modifications in below-ground functioning, we measured soil, plant and nectar variables.

\section{Soil traits}

Nitrogen and water are the most important common soil resources for plant growth. Total nitrogen content of biomass in plant communities was measured in order to determine the nitrogen supplied to the plants during the experiment (see methods below). When comparing similar communities, this measure can be seen as a proxy for the nitrogen supply capacity of the soil (van Eekeren et al. 2010). We also measured the final soil humidity in pots with a TethaProbe ML2 (Delta-T Devices, Cambridge, UK) to estimate water requirements of plant communities. Soil traits thus encompassed final humidity (\%) and nitrogen supplied to communities $\left(\mathrm{mg} \mathrm{pot}^{-1}\right)$.

\section{Plant traits}

At the end of the experiment, above-ground material of all plants was harvested, oven-dried $\left(65^{\circ} \mathrm{C} ; 48 \mathrm{~h}\right)$ and weighed. Shoots from all individual plants of the same species from each pot were pooled to have enough dry matter for quantification. Shoot carbon and nitrogen contents were measured using a CHN Elemental Analyser (NA 1500 Series 2, Fisons, Manchester, UK). Throughout the experiment, the number of flowers of each individual plant was recorded weekly and the flower display size (i.e. largest number of opened flowers counted at once on individuals) was determined. Plant traits thus encompassed final above-ground biomass $\left(\mathrm{g} \mathrm{plant}^{-1}\right)$, final shoot $\mathrm{C}: \mathrm{N}$ ratio $\left(\mathrm{g} \mathrm{g}^{-1}\right)$ and floral display size (number of flowers plant ${ }^{-1}$ ) as indicators of quality of plant nutrition.

\section{Nectar traits}

Nectar was sampled from the beginning of the flowering period (after 35, 42 and 49 days for L. amplexicaule, M. guttatus and 
$M$. sativa, respectively) until the end of the experiment. Because flower age influences nectar composition (Petanidou, VanLaere \& Smets 1996), nectar was only collected in flowers that had been open for one day: in total 604 flowers of M. guttatus, 551 of L. amplexicaule and 236 of M. sativa. The volume of nectar was determined by measuring the length of liquid in the microcapillary used for nectar sampling ( $1 \mu \mathrm{L}$ Drummond Microcaps ${ }^{\circledR}$, Drummond Scientific Co., Broomall, Pa., USA). Nectar sugar composition (e.g. glucose, fructose and saccharose contents) was analysed by High Performance Anion Exchange Chromatography Pulsed Amperometric Detection (HPAEC-PAD, ICS-3000 Dionex). Due to the quantification threshold, samples were pooled by plant species for each pot. Consequently, chemical analyses were done on 66, 87 and 23 distinct samples of nectar from M. guttatus, L. amplexicaule and M. sativa, respectively. Separation was achieved on a CarboPac PA-1 anion-exchange column $(4 \times 250 \mathrm{~mm}$, Dionex $)$ thermostated at $30^{\circ} \mathrm{C}$. Elution was performed with a $48: 52$ (vol:vol) mixture of ultrapure water (MilliQ, Millipore Corporation, Billerica, MA., USA) and a solution of $\mathrm{NaOH}(250 \mathrm{mM})$ with $\mathrm{NaOAc}(4 \mathrm{mM})$ at constant flow $\left(0.7 \mathrm{~mL} \mathrm{~min}^{-1}\right)$. Nectar traits thus encompassed nectar volume $\left(\mu \mathrm{L}\right.$ flower ${ }^{-1}$ ), nectar sugar concentration $\left(\mathrm{nmol} \mu \mathrm{L}^{-1}\right)$ and nectar di-/monosaccharide ratio $\left(\mathrm{g} \mathrm{g}^{-1}\right)$ to depict nectar quantity, quality and composition. In order to compute an integrative index of plant attractiveness to pollinators, total sugar content in nectar potentially available to pollinators at plant level was estimated as the product of the mean quantity of sugar per flower by the mean floral display size per plant ( $\mu \mathrm{g}$ of sugars plant ${ }^{-1}$ ).

\section{STATISTICAL ANALYSES}

The three sets of variables: soil traits (humidity and nitrogen supplied), plant traits (final biomass, shoot $\mathrm{C}: \mathrm{N}$ ratio and floral display size) and nectar traits (nectar volume, sugar concentration and di-/monosaccharide ratio) were analysed by multivariate analyses of variance (MANova Pillai tests) after log-transformation. Protected Anovas were subsequently used for each response variable only when multivariate significance was granted. Type III analyses of variance were done after backward simplification. Tukey post hoc tests were used to determine the significant differences among treatments. Total sugar content in nectar was analysed by linear model fitting using square-root-transformed data. Because plant interactions within plant communities are, per se, linked to focal plant species, statistical analyses of plant and nectar traits were performed for each focal plant species, with 'plant interaction', 'litter' and their interaction as fixed factors. All analyses were carried out using R 2.10.1 (R development core team 2010).

\section{Results}

\section{SOIL TRAITS}

The MANOva performed on the set of soil properties (humidity and nitrogen supplied) revealed a highly significant effect of litter amendments (d.f. $=8, F=5.6, P<0.001$ ) and plant interactions (d.f. $=12, F=7.6, P<0.001$ ). However, no interaction between litter and plant interaction treatments was observed.

Pots that received litter were significantly drier than pots without litter (d.f. $=4, F=1.0, P<0.01$ ), with the exception of litter of $M$. guttatus (Tukey test: $P=0.16$ ). Regardless of the identity of litter, the addition of litter to the soils improved the soil nitrogen supply capacity since plant communities incorporated more nitrogen when grown on soil with litter (d.f. $=4, F=0.7, P<0.001)$. The observed significant effect of plant interactions on soil humidity (d.f. $=6$, $F=1.19, P<0.001$ ) was only due to the $M$. sativa monocultures, the soils of which were drier than those of all other plant communities (least significant Tukey tests: $P=0.04$ ), with the exception of $M$. sativa and $M$. guttatus mixtures $(P=0.63)$. The effect of plant interactions on nitrogen supplied to plants (d.f. $=6, F=1.84, P<0.001$ ) was due, on the one hand, to monocultures of $L$. amplexicaule that contained less nitrogen than other communities (least significant: $P=0.02$ ), and on the other hand, to monocultures of $M$. sativa (least significant: $P<0.001$ ) and mixtures of $M$. sativa and M. guttatus (least significant: $P=0.06$ ) that contained more nitrogen than other communities.

\section{PLANT TRAITS}

Values of plant and nectar traits of each plant species used in the experiment are summarized in Table 1. The MANOvas performed over the set of plant traits (biomass, shoot $\mathrm{C}: \mathrm{N}$ ratio and floral display size) revealed significant effects of litter inputs and plant interactions, but no interaction between these treatments was detected (Table 2).

Litter treatments significantly impacted final above-ground biomass and shoot $\mathrm{C}: \mathrm{N}$ ratio in L. amplexicaule and floral display size in M. guttatus but did not influence any plant traits in M. sativa (Table 3; see Fig. S1 in Supporting Information).

Table 1. Plant and nectar traits for the three plant species M. guttatus, L. amplexicaule and M. sativa used in the experiment

\begin{tabular}{|c|c|c|c|c|c|c|}
\hline & \multicolumn{2}{|c|}{ Mimulus guttatus } & \multicolumn{2}{|c|}{ Lamium amplexicaule } & \multicolumn{2}{|c|}{ Medicago sativa } \\
\hline & Mean \pm SE & $n$ & Mean $\pm \mathrm{SE}$ & $n$ & Mean $\pm \mathrm{SE}$ & $n$ \\
\hline Above-ground biomass (g plant ${ }^{-1}$ ) & $0.95 \pm 0.04$ & (77) & $0.30 \pm 0.02$ & $(76)$ & $0.36 \pm 0.03$ & $(72)$ \\
\hline Shoot C:N ratio $\left(\mathrm{g} \mathrm{g}^{-1}\right)$ & $37.9 \pm 0.7$ & (77) & $31.6 \pm 0.9$ & (76) & $20.6 \pm 0.8$ & (72) \\
\hline Floral display size (number of flowers plant ${ }^{-1}$ ) & $2.6 \pm 0.2$ & (77) & $7.1 \pm 0.5$ & (76) & $0.3 \pm 0.05$ & $(72)$ \\
\hline Nectar volume $\left(\mu\right.$ flower $\left.^{-1}\right)$ & $0.12 \pm 0.01$ & (30) & $0.35 \pm 0.02$ & (63) & $0.04 \pm 0.01$ & (21) \\
\hline Nectar sugar concentration $\left(\mathrm{nmol} \mu \mathrm{L}^{-1}\right)$ & $101.7 \pm 8.1$ & $(30)$ & $115.6 \pm 5.5$ & $(63)$ & $287.7 \pm 25.3$ & $(21)$ \\
\hline Nectar di-/monosaccharide ratio $\left(\mathrm{g} \mathrm{g}^{-1}\right)$ & $110.9 \pm 35.3$ & (30) & $2.4 \pm 0.1$ & (63) & $0.9 \pm 0.1$ & (21) \\
\hline Nectar sugar content $\left(\mu\right.$ g plant $\left.^{-1}\right)$ & $9.1 \pm 1.0$ & (62) & $68.3 \pm 5.7$ & (65) & $2.4 \pm 0.7$ & $(22)$ \\
\hline
\end{tabular}


Table 2. Summary of the effects of litter input and plant interaction on plant traits and nectar traits in M. guttatus, L. amplexicaule and M. sativa. Multivariate tests (MANOva Pillai tests)

\begin{tabular}{|c|c|c|c|c|c|c|c|c|c|c|c|c|c|c|c|}
\hline \multirow[b]{2}{*}{ Source of variation } & \multicolumn{5}{|c|}{ Mimulus guttatus } & \multicolumn{5}{|c|}{ Lamium amplexicaule } & \multicolumn{5}{|c|}{ Medicago sativa } \\
\hline & $\begin{array}{l}\text { Num } \\
\text { d.f.* }\end{array}$ & $\begin{array}{l}\text { Den } \\
\text { d.f.* }\end{array}$ & $\begin{array}{l}\text { Pillai } \\
\text { test }\end{array}$ & $F$ & $P$ & $\begin{array}{l}\text { Num } \\
\text { d.f.* }\end{array}$ & $\begin{array}{l}\text { Den } \\
\text { d.f.* }\end{array}$ & $\begin{array}{l}\text { Pillai } \\
\text { test }\end{array}$ & $F$ & $P$ & $\begin{array}{l}\text { Num } \\
\text { d.f.* }\end{array}$ & $\begin{array}{l}\text { Den } \\
\text { d.f.* }\end{array}$ & $\begin{array}{l}\text { Pillai } \\
\text { test }\end{array}$ & $F$ & $P$ \\
\hline \multicolumn{16}{|l|}{ Plant traits } \\
\hline Litter input & 12 & 207 & 0.46 & 3.11 & 0.001 & 12 & 204 & 0.48 & 3.23 & 0.001 & 12 & 192 & 0.30 & 1.76 & 0.057 \\
\hline Plant association & 9 & 207 & 0.61 & 5.86 & $<.0001$ & 9 & 204 & 0.81 & 8.42 & $<.0001$ & 9 & 192 & 0.27 & 2.10 & 0.031 \\
\hline \multicolumn{16}{|l|}{ Nectar traits } \\
\hline Litter input & 12 & 66 & 0.39 & 0.81 & 0.639 & 12 & 165 & 0.19 & 0.93 & 0.521 & 12 & 39 & 0.62 & 0.84 & 0.605 \\
\hline Plant association & 9 & 66 & 0.66 & 2.06 & 0.045 & 9 & 165 & 0.41 & 2.94 & 0.003 & 9 & 39 & 0.65 & 1.20 & 0.321 \\
\hline
\end{tabular}

Data were log-transformed before multivariate analyses; see text for details of analyses.

*Num d.f. and Den d.f. correspond to numerator and denominator degrees of freedom, respectively.

Table 3. Summary of the effects of litter input and plant interaction on plant traits (above-ground biomass, shoot C:N ratio, floral display size) and nectar traits (nectar volume, nectar sugar concentration, nectar sugar ratio) in M. guttatus and L. amplexicaule and M. sativa. Univariate tests (Protected Anovas)

\begin{tabular}{|c|c|c|c|c|c|c|c|c|c|c|c|c|}
\hline & \multicolumn{4}{|c|}{ Mimulus guttatus } & \multicolumn{4}{|c|}{ Lamium amplexicaule } & \multicolumn{4}{|c|}{ Medicago sativa } \\
\hline & d.f.* & MS* & $F$ & $P$ & d.f.* & MS* & $F$ & $P$ & d.f.* & MS* & $F$ & $P$ \\
\hline \multicolumn{13}{|l|}{ Litter input effect } \\
\hline Above-ground biomass & 4 & 0.009 & 2.26 & 0.071 & 4 & 0.009 & 5.68 & 0.001 & $\dagger$ & $\dagger$ & $\dagger$ & $\dagger$ \\
\hline $\mathrm{C}: \mathrm{N}$ ratio & 4 & 0.007 & 1.70 & 0.159 & 4 & 0.020 & 2.99 & 0.025 & $\dagger$ & $\dagger$ & $\dagger$ & $\dagger$ \\
\hline Floral display size & 4 & 0.126 & 3.28 & 0.016 & 4 & 0.082 & 0.19 & 0.189 & $\dagger$ & $\dagger$ & $\dagger$ & $\dagger$ \\
\hline \multicolumn{13}{|l|}{ Plant interaction effect } \\
\hline Above-ground biomass & 3 & 0.023 & 5.99 & 0.001 & 3 & 0.016 & 10.31 & $<.0001$ & 3 & 0.021 & 4.35 & 0.007 \\
\hline $\mathrm{C}: \mathrm{N}$ ratio & 3 & 0.042 & 10.68 & $<.0001$ & 3 & 0.118 & 17.91 & $<.0001$ & 3 & 0.046 & 3.38 & 0.023 \\
\hline Floral display size & 3 & 0.006 & 0.15 & 0.926 & 3 & 0.298 & 5.73 & 0.001 & 3 & 0.039 & 2.74 & 0.050 \\
\hline Nectar volume & 3 & 0.001 & 1.83 & 0.171 & 3 & 0.007 & 3.46 & 0.022 & $\dagger$ & $\dagger$ & $\dagger$ & $\dagger$ \\
\hline Nectar sugar concentration & 3 & 0.008 & 0.22 & 0.882 & 3 & 0.032 & 1.72 & 0.172 & $\dagger$ & $\dagger$ & $\dagger$ & $\dagger$ \\
\hline Nectar sugar ratio & 3 & 1.54 & 2.39 & 0.096 & 3 & 0.020 & 2.53 & 0.067 & $\dagger$ & $\dagger$ & $\dagger$ & $\dagger$ \\
\hline
\end{tabular}

Data were log-transformed before univariate analyses; see text for details of analyses.

*d.f. corresponds to degrees of freedom and MS to square means.

†indicated non-allowed protected ANOvas.

More precisely, the addition of $M$. sativa litter increased the biomass of L. amplexicaule plants by $68 \%$ relative to no litter, M. guttatus litter or tri-species mixture litter treatments (least significant: $P=0.03$ ). The addition of litter, especially that of L. amplexicaule, also led to an $18 \%$ decrease of the shoot $\mathrm{C}: \mathrm{N}$ ratio of $L$. amplexicaule plants $(P=0.01)$. The effect of litter inputs on the floral display size of $M$. guttatus was due to litter of L. amplexicaule that induce an increase of $91 \%$ compared to no litter or to $M$. sativa litter treatments (least significant: $P=0.05$ ). More generally, the addition of litter improved biomass and C:N ratio plant traits of $L$. amplexicaule (d.f. $=3$, $F=5.45, P<0.01$ ) and $M$. guttatus (d.f. $=3, F=5.44$, $P<0.01$ ) but not those of M. sativa (d.f. $=3, F=2.24$, $P=0.09$; see Fig. S1).

Regardless of the focal plant species, the plant interaction treatment had a significant impact on plant traits (Table 2). In the cases of M. guttatus and L. amplexicaule, the effects of plant interaction on plant traits were seen mainly when
M. guttatus was present in the communities (Table 3; see Fig. S2). When grown with M. guttatus, the above-ground biomass of $L$. amplexicaule plants was reduced by $42 \%$ and its shoot C:N ratio increased by $44 \%$ compared to those in monoculture or in two-species mixtures with $M$. sativa (least significant: $P=0.02$ ). In three-species mixture, plants of $L$. amplexicaule also showed a reduced biomass and a higher shoot $\mathrm{C}: \mathrm{N}$ ratio than those in two-species mixture with $M$. sativa (least significant: $P=0.04$ ). Then, floral display size of $L$. amplexicaule was significantly reduced when grown in threespecies mixture relative to plants in monoculture and in twospecies mixtures with $M$. sativa (least significant: $P=0.01$ ). Mimulus guttatus also had its biomass reduced by $30 \%$ and C:N increased by $20 \%$ when grown in monoculture compared to all other treatments (least significant: $P=0.02$ ). In the case of $M$. sativa, analyses indicated significantly higher biomass and lower $\mathrm{C}: \mathrm{N}$ ratio in monocultures relative to three-species mixtures (Table 3; least significant: $P=0.05$; see Fig. S2). 


\section{NECTAR TRAITS}

None of the nectar traits (nectar volume per flower, sugar concentration and di-/monosaccharide ratio) of the three plant species was significantly affected by litter regardless of its identity (see Fig. S3), and no interaction between litter and plant interaction treatments was observed (Table 2). However, MANOVAS indicated that the nectar traits of L. amplexicaule and $M$. guttatus, but not those of $M$. sativa, were sensitive to plant interactions (Table 2).

In L. amplexicaule, plant interactions strongly affected the volume of nectar per flower but did not significantly influence the sugar concentration or the di-/monosaccharide ratio in the nectar (Table 3; see Fig. S4). Lamium amplexicaule plants grown in two-species mixtures with $M$. guttatus showed a tendency to reduce volume of nectar per flower compared with mono $(P=0.06)$ and three-species mixtures $(P=0.02)$. In M. guttatus, univariate ANovas did not reveal significant effects of plant interactions on independent nectar traits (Table 3).

\section{TOTAL SUGAR CONTENT OF NECTAR AVAILABLE TO POLLINATORS AT PLANT LEVEL}

Once again, no significant interaction between plant interaction and litter treatments was detected on sugar content in nectar at the plant level in any species, but simple significant effects were found in L. amplexicaule.
Regardless of the focal plant species, no effect of litter treatment on the total sugar content of nectar was found. Nevertheless, analyses performed by grouping litter treatments according to 'with' or 'without' litter showed that the addition of litter significantly increased total sugar content in nectar of L. amplexicaule (d.f. $=1, F=4.53, P=0.04$ ) but not in $M$. guttatus (d.f. $=1, F=1.26, P=0.27$ ) or in $M$. sativa (d.f. $=1, F=3.98, P=0.07$ ). On average, litter amendments led to an increase of $65 \%$ of sugar content in nectar at plant level in L. amplexicaule, compared to treatments without litter (Fig. 2).

Plant interaction within communities also significantly affected the total sugar content of nectar in plants of $L$. amplexicaule (d.f. $=3, F=5.09, P<0.01$ ) but not in M. guttatus and M. sativa. When grown with $M$. guttatus, plants of L. amplexicaule provided a $56 \%$ lower nectar sugar content to pollinators than those in monoculture or in mixture with M. sativa (Fig. 2; least significant: $P=0.02$ ).

\section{Discussion}

We investigated how modifications in below-ground functioning in plant communities influenced above-ground floral traits involved in plant attractiveness to pollinators. Our results indicate that total sugar content in nectar of L. amplexicaule was increased by litter amendment and strongly reduced by competitive interaction with $M$. guttatus, which is in accordance

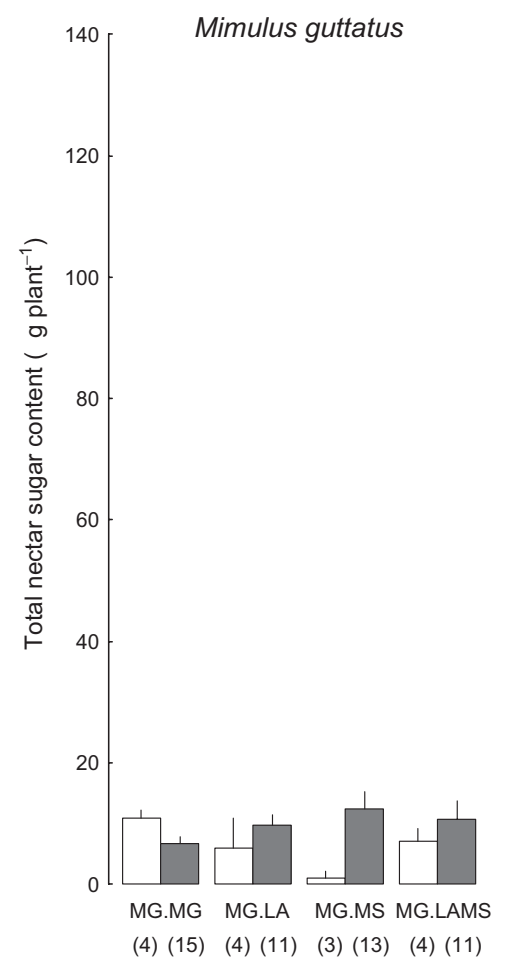

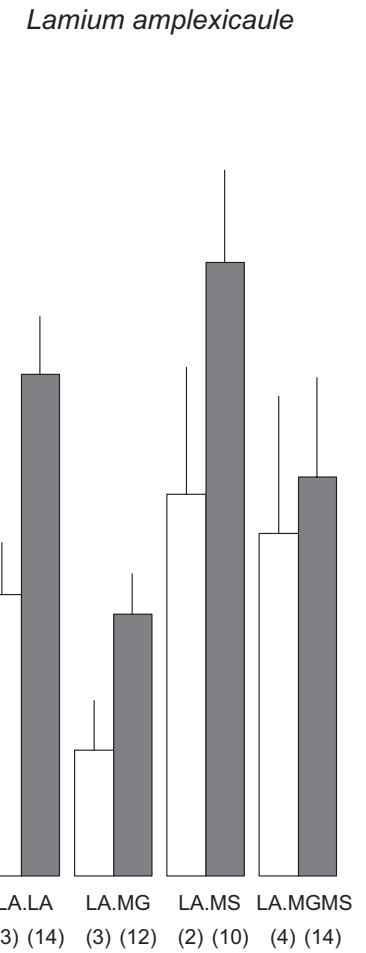

Plant interaction
Medicago sativa

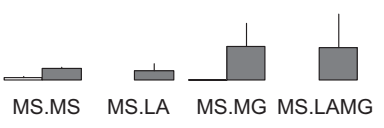

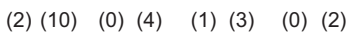

Fig. 2. Mean total sugar content in nectar available to pollinators at the plant level ( $\mu$ g plant ${ }^{-1}$ ) in M. guttatus, L. amplexicaule and $M$. sativa according to plant association and litter addition. Open bars represent treatments without litter amendment; shaded bars represent treatments with litter amendment (all litter identity confound). Plant interaction is coded with the first two letters referring to the focal plant species and the last two letters to the associated plant species. Numbers in brackets under bars indicate the number of replicates (pots). Error bars are $+1 \mathrm{SE}$. 
with our predictions in Fig. 1. However, nectar traits of L. amplexicaule were not affected by facilitative interaction with $M$. sativa. On the other hand, nectar traits of M. guttatus and $M$. sativa were less sensitive to experimental treatments, showing that the validity of the predictions in Fig. 1 depends upon the focal plant species considered. In the following, we will discuss sequentially the effects of litter and plant interactions on soil, plant and nectar traits. We will then discuss the implications for pollination.

\section{LITTER INPUTS}

Litter quantity, identity and diversity are known to affect below-ground functioning (Bardgett \& Shine 1999; Bowman et al. 2004; Meier \& Bowman 2008) as well as above-ground primary productivity (Nilsson, Wardle \& Dahlberg 1999; Bowman et al. 2004; Dehlin, Nilsson \& Wardle 2006; Quested \& Eriksson 2006; Nilsson, Wardle \& DeLuca 2008). The role of below-ground on above-ground biota including pollinators has already been investigated (Poveda et al. 2003, 2005; Wolfe, Husband \& Klironomos 2005), but less is known about how litter affects floral and nectar traits.

Regardless of origin, litter amendment increased the nitrogen supply capacity of the soil, as expected (Fig. 1). This resulted in more plant growth and a greater water requirement of plant communities, hence the observed low soil humidity in pots with litter. However, litter effects on plant traits were very dependent on the focal species considered. The increase in above-ground biomass and the decrease in shoot $\mathrm{C}: \mathrm{N}$ ratio with litter amendment in $L$. amplexicaule, and similarly, but less intensively, in $M$. guttatus, suggest that litter amendment lowered nutrient limitations. This was probably due to the release of nutrients from the litter amendment (Quested, Callaghan \& Press 2003) or to the stimulation of soil organic matter mineralization (Bardgett \& Shine 1999). Positive (Quested \& Eriksson 2006; Nilsson, Wardle \& DeLuca 2008) and negative effects of litter inputs (Bowman et al. 2004; Dehlin, Nilsson and Wardle 2006) on vegetation have been reported previously. In these latter cases, litter with high $\mathrm{C}: \mathrm{N}$ ratio could have caused the soil micro-organisms to immobilize nutrients necessary for plant growth (Bowman et al. 2004). Litter amendments, on the other hand, did not affect plant traits of $M$. sativa. The fact that nodules were observed on the root system of $M$. sativa (data not shown) suggests that this species was able to symbiotically fix atmospheric nitrogen, making it less dependent on soil nitrogen availability.

The effects of litter identity varied depending upon the plant trait and the focal plant species considered, supporting the great variability of litter inputs on vegetation (Quested \& Eriksson 2006). Whilst litter of $L$. amplexicaule and $M$. sativa occasionally affected plant traits, that of M. guttatus never had any effect despite the lower C:N and C:P ratios. The magnitude of litter amendment effects on plant traits did not correlate with the initial litter stoichiometry, which is in accordance with the results of Bardgett \& Shine (1999) that show that the decomposition rate of litters from grassland was not necessarily related to litter nutrient content. There might have been a lower release of nutrients from M. guttatus litter due to the carbon quality of this litter (Hättenschwiller and Jorgensen 2010). However, we cannot exclude the possibility that such variations in responses are the result of a lack of statistical power in the experiment.

Mineral soil fertilization is known to stimulate the production of flowers (Campbell \& Halama 1993; Juenger \& Bergelson 1997; Muñoz et al. 2005; Burkle \& Irwin 2009a, 2010), but the presence of litter did not have the same effect, with the exception of a positive effect of litter of $L$. amplexicaule on the floral display size of $M$. guttatus. A poor synchronization between the release of nutrients from the litter amendment and the flowering might explain the lack of strong effects, especially in L. amplexicaule. Finally, none of the nectar traits (nectar volume per flower, sugar concentration and di-/monosaccharide ratio) of the three species studied was affected by the presence of litter, regardless of litter identity. Nevertheless, the addition of litter was found to enhance the total nectar sugar content in L. amplexicaule at the plant level due to the integration of several modifications in nectar and plant properties. Plants of $L$. amplexicaule grown with litter supplied nearly $56 \%$ more nectar sugars than plants without litter (Fig. 2). This suggests that soil litter amendment can enhance individual plant attractiveness to pollinators at the plant scale as expected (Fig. 1), but only in some species. Differential responses to nitrogen addition are known to depend on lifehistory. Annual species are more sensitive to variations in nitrogen availability, whereas the response of perennials is often delayed due to their ability to store resources and their flexibility in resource allocation to biomass and reproduction (Burkle \& Irwin 2009a; 2010).

\section{PLANT INTERACTIONS}

By taking up nutrients and providing carbon to soil, plants affect below-ground processes (Casper \& Jackson 1997), which in turn can affect above-ground plant communities (Wardle et al. 2004). These effects can be due to particular species (e.g. legumes; Temperton et al. 2007) or particular assemblages of species (Milcu et al. 2006).

We found that $M$. sativa, whether alone or in mixture with $M$. guttatus had a positive influence on total nitrogen acquisition. This was due to the nitrogen fixing capacity of $M$. sativa. Medicago sativa plants in monocultures presented the highest biomass and lowest shoot $\mathrm{C}: \mathrm{N}$ ratio, which explained the greater water consumption in these communities. In contrast to our initial predictions (Fig. 1), the effect of M. sativa on the neighbouring plants in the communities was weak: we found no statistical evidence that the presence of $M$. sativa in two-species mixtures improved plant traits of other species. Although it has been shown that legumes can improve the growth of neighbouring plants (Temperton et al. 2007), this is particularly true for grasses, but less so for herbs. Consequently, none of the nectar traits of plant species were improved by the presence of $M$. sativa within communities. Despite the fact that 
vegetative traits of $M$. sativa were improved in monoculture, we did not find significant effects on floral display size, probably because the flower production was very low.

Plant traits of L. amplexicaule and M. guttatus were negatively affected by competitive interaction with $M$. guttatus in communities. When grown in association with M. guttatus, L. amplexicaule and M. guttatus plants presented a reduced biomass and a higher shoot $\mathrm{C}: \mathrm{N}$ ratio. This explicitly revealed the effects of inter- and intra-specific competition with M. guttatus, possibly through an increased exploitation of soil nitrogen. Indeed, rapid growth of $M$. guttatus constituted a strong competitive attribute of this species (Truscott et al. 2006) for soil nitrogen acquisition. As vegetative traits of $L$. amplexicaule and $M$. guttatus positively responded to nutrient addition released by litter, they also negatively responded to nutrient depletion by the presence of $M$. guttatus. This translated to a reduction in floral display size only in L. amplexicaule but not in M. guttatus.

Most importantly, the competitive attributes of M. guttatus led to a reduced sugar content in the nectar of L. amplexicaule (Fig. 2). This resulted from a combined decrease in mean volume of nectar per flower and in floral display size. To our knowledge, this is the first experimental demonstration that competition among plants for soil resources can have an impact on plant traits linked to attractiveness to pollinators, as predicted in Fig. 1. On the other hand, nectar traits of M. guttatus and $M$. sativa were not affected by plant interactions within communities, contrary to what was expected (Fig. 1). The literature seems to suggest that the responses of nectar traits to soil mineral fertilization are idiosynchratic: positive (Campbell \& Halama 1993; Petanidou, Goethals \& Smets 1999; Burkle \& Irwin 2009a), neutral (Petanidou, Goethals \& Smets 1999; Erhardt, Rusterholz \& Stocklin 2005; Burkle \& Irwin 2009a) or negative effects (Petanidou, Goethals \& Smets 1999) have been observed. The species M. guttatus and M. sativa might be less sensitive to competition for resources for the reasons explained above (Burkle \& Irwin 2009a; 2010). The effects may also have been too weak to be detected because of the small nectar volumes per flower (especially in $M$. sativa, see Table 1).

Finally, no significant interactions between plant association and litter inputs were detected, suggesting that the presence of litter did not affect the magnitude of plant-plant interactions. It differed from observations made by Ladd \& Facelli (2008) who demonstrated that litter could modify plant interactions. Litter effects on seedling emergence, which were not considered in our experiment, were found as the main mechanism in modification of plant interaction by litter.

\section{IMPLICATIONS FOR POLLINATION}

According to foraging economics, nectar availability and floral displays are the most important traits influencing attractiveness of plants to pollinators (Kudo \& Harder 2005). Flower visitors' foraging benefits are directly linked to nectar availability and foraging costs depend on the flight distance among flowers, which is likely to be reduced with larger floral displays.
Plants with larger floral displays (Ohashi \& Yahara 2001; Kudo \& Harder 2005) or with higher nectar production per flower (Klinkhamer \& de Jong 1990; Klinkhamer, de Jong \& Linnebank 2001; Kudo \& Harder 2005) attract more pollinators.

In our pot experiment, we showed that amendment of a quantity of litter of the same order of magnitude as that found in natural grasslands (Schlesinger 1997) can enhance the total sugar content of nectar in L. amplexicaule but not in M. guttatus and M. sativa. In natural situations, litter amendment to the soil from species that composed the community should thus enhance attractiveness of plant species that are the most dependent on below-ground resources. Due to species-specific sensitivity of plants to litter inputs, we thus hypothesize that litter management practices would alter plant-pollinator interaction networks at the community level (Burkle \& Irwin 2009b).

Furthermore, we found that M. guttatus, the most competitive species in our experiment, strongly altered nectar sugar content in L. amplexicaule. Since M. guttatus and L. amplexicaule share common pollinators, the introduction of M. guttatus in European natural grasslands might decrease L. amplexicaule attractiveness to pollinators in favour of M. guttatus (Fig. 1). Pollination of L. amplexicaule might therefore suffer from competitive interactions with M. guttatus (Waser 1978; Brown, Mitchell \& Graham 2002; Bell, Karron $\&$ Mitchell 2005), which could have negative consequences for L. amplexicaule fitness since the quality of its reproduction depends upon pollinators (Lord 1978). This highlights alternative mechanisms by which invasive plant species could alter natural community dynamics.

Overall, our experiment underlines the importance of taking into account interactions between plants for soil resources in studying plant-plant interactions for pollinator access (Waser 1978; Chittka \& Schurkens 2001; Brown, Mitchell \& Graham 2002; Moeller 2004; Bell, Karron \& Mitchell 2005; Torang, Ehrlen \& Agren 2006). Since non-attractive plants such as wind-pollinated species are also involved in plant interactions for soil resources, such species might indirectly alter plantpollinator networks, by affecting insect-pollinated floral and nectar traits involved in plant attractiveness to pollinators.

\section{Acknowledgements}

We are grateful to Elodie Alapetite, Adélaïde Roguet and Marion Demarcy for their valuable help with experiment setting up and data collection. We also thank Colin Fontaine, Gérard Lacroix, Florence Maunoury-Danger and Elisa Thébault for productive discussion on the experiment. Earlier drafts of the manuscript benefited from insightful comments from Richard Michalet, Luc Gigord and Theodora Petanidou. We also thank the Associate Editor and two anonymous referees for constructive and useful comments.

\section{References}

Adler, L.S., Wink, M., Distl, M. \& Lentz, A.J. (2006) Leaf herbivory and nutrients increase nectar alkaloids. Ecology Letters, 9, 960-967.

Allen-Wardell, G., Bernhardt, P., Bitner, R., Burquez, A., Buchmann, S., Cane, J. et al. (1998) The potential consequences of pollinator declines on the conservation of biodiversity and stability of food crop yields. Conservation Biology, 12, 8-17. 
Baker, H.G. \& Baker, I. (1979) Sugar ratios in nectars. Phytochemical Bulletin, 12, $43-45$.

Bardgett, R.D. \& Shine, A. (1999) Linkages between plant litter diversity, soil microbial biomass and ecosystem function in temperate grasslands. Soil Biology and Biochemistry, 31, 317-321.

Bell, J.M., Karron, J.D. \& Mitchell, R.J. (2005) Interspecific competition for pollination lowers seed production and outcrossing in Mimulus ringens. Ecology, 86, 762-771.

Biesmeijer, J.C., Roberts, S.P.M., Reemer, M., Ohlemuller, R., Edwards, M., Peeters, T., Schaffers, A.P., Potts, S.G., Kleukers, R., Thomas, C.D., Settele, J. \& Kunin, W.E. (2006) Parallel declines in pollinators and insect-pollinated plants in Britain and The Netherlands. Science, 313, 351-354.

Bowman, W.D., Steltzer, H., Rosenstiel, T.N., Cleveland, C.C. \& Meier, C.L. (2004) Litter effects of two co-occurring alpine species on plant growth, microbial activity and immobilization of nitrogen. Oikos, 104, 336-344.

Brink, R.A. \& Cooper, D.C. (1938) Partial self-incompatibility in Medicago sativa. Proceedings of the National Academy of Sciences of the United States of America, 24, 497-499.

Brookes, B., Small, E., Lefkovitch, L.P., Damman, H. \& Fairey, D.T. (1994) Attractiveness of alfafa (Medicago sativa $\mathrm{L}$.) to wild pollinators in relation to wildflowers. Canadian Journal of Plant Science, 74, 779-783.

Brown, B.J., Mitchell, R.J. \& Graham, S.A. (2002) Competition for pollination between an invasive species (purple loosestrife) and a native congener. Ecology, 83, 2328-2336.

Burkle, L.A. \& Irwin, R.E. (2009a) The effects of nutrient addition on floral characters and pollination in two subalpine plants, Ipomopsis aggregata and Linum lewisii. Plant Ecology, 203, 83-98.

Burkle, L.A. \& Irwin, R.E. (2009b) The importance of interannual variation and bottom-up nitrogen enrichment for plant-pollinator networks. Oikos, 118, 1816-1829.

Burkle, L.A. \& Irwin, R.E. (2010) Beyond biomass: measuring the effects of community-level nitrogen enrichment on floral traits, pollinator visitation and plant reproduction. Journal of Ecology, 98, 705-717.

Campbell, D.R. \& Halama, K.J. (1993) Resource and pollen limitations to lifetime seed production in a natural plant-population. Ecology, 74, 1043-1051.

Carvell, C., Roy, D.B., Smart, S., Pywell, R.F., Preston, C.D. \& Goulson, D (2006) Declines in forage availability for bumblebees at a national scale. Biological Conservation, 132, 481-489.

Carvell, C., Meek, W.R., Pywell, R.F., Goulson, D. \& Nowakowski, M. (2007) Comparing the efficiency of agri-environment schemes to enhance bumble bee abundance and diversity on arable field margins. Journal of Applied Ecology, 44, 29-40.

Casper, B.B. \& Jackson, R.B. (1997) Plant competition underground. Annual Review Ecology and Systematics, 28, 545-570.

Castellanos, M.C., Wilson, P. \& Thomson, J.D. (2002) Dynamic nectar replenishment in flowers of Penstemon (Scrophulariaceae). American Journal of Botany, 89, 111-118.

Chittka, L. \& Schurkens, S. (2001) Successful invasion of a floral market - An exotic Asian plant has moved in on Europe's river-banks by bribing pollinators. Nature, 411, 653-653.

Cresswell, J.E. (1999) The influence of nectar and pollen availability on pollen transfer by individual flowers of oil-seed rape (Brassica napus) when pollinated by bumblebees (Bombus lapidarius). Journal of Ecology, 87, 670-677.

Dafni, A. (1992) Pollination Ecology: A Pratical Approach. Oxford University Press, Oxford.

Dehlin, H., Nilsson, M.C. \& Wardle, D.A. (2006) Aboveground and belowground responses to quality and heterogeneity of organic inputs to the boreal forest. Oecologia, 150, 108-118.

van Eekeren, N., de Boer, H., Hanegraaf, M., Bokhorst, J., Nierop, D., Bloem, J., Schouten, T., de Goede, R. \& Brussaard, L. (2010) Ecosystem services in grassland associated with biotic and abiotic soil parameters. Soil Biology \& Biochemistry, 42, 1491-1504.

Erhardt, A., Rusterholz, H.P. \& Stocklin, J. (2005) Elevated carbon dioxide increases nectar production in Epilobium angustifolium L. Oecologia, 146, 311-317.

Gardener, M.C. \& Gillman, M.P. (2001) The effects of soil fertilizer on amino acids in the floral nectar of corncockle, Agrostemma githago (Caryophyllaceae). Oikos, 92, 101-106.

Hättenschwiller, S. \& Jorgensen, B. (2010) Carbon quality rather than stoichoimetry controls litter decomposition in a tropical forest. Journal of Ecology, 98, 754-763.

Herrera, C.M., Perez, R. \& Alonso, C. (2006) Extreme intraplant variation in nectar sugar composition in an insect-pollinated perennial herb. American Journal of Botany, 93, 575-581.
Hill, M.O., Mountford, J.O., Roy, D.B. \& Bunce, R.G.H. (1999) Ellenberg's Indicator Values for British plants. ECO-FACT Volume 2, Technical Annex, pp. 46. Institute of Terrestrial Ecology, Cambridgeshire, UK.

Juenger, T. \& Bergelson, J. (1997) Pollen and resource limitation of compensation to herbivory in scarlet gilia, Ipomopsis aggregata. Ecology, 78, 1684 1695.

Kearns, C.A., Inouye, D.W. \& Waser, N.M. (1998) Endangered mutualisms: the conservation of plant-pollinator interactions. Annual Review of Ecology Evolution and Systematics, 29, 83-112.

Klinkhamer, P.G.L. \& de Jong, T.J. (1990) Effects of plant size, plant density and sex differential nectar reward on pollinator visitation in the protandrous Echium vulgare (Boraginaceae). Oikos, 57, 399-405.

Klinkhamer, P.G.L., de Jong, T.J. \& Linnebank, L.A. (2001) Small-scale spatial patterns determine ecological relationships: an experimental example using nectar production rates. Ecology Letters, 4, 559-567.

Kremen, C. \& Ricketts, T. (2000) Global perspectives on pollination disruptions. Conservation Biology, 14, 1226-1228.

Kudo, G. \& Harder, L.D. (2005) Floral and inflorescence effects on variation in pollen removal and seed production among six legume species. Functional Ecology, 19, 245-254.

Ladd, B. \& Facelli, J.M. (2008) Priority effects produced by plant litter result in non-additive competitve effects. Oecologia, 157, 687-696.

Lanza, J., Smith, G.C., Sack, S. \& Cash, A. (1995) Variation in nectar volume and composition of Impatiens capensis at the individual, plant, and population-levels. Oecologia, 102, 113-119.

Lau, T.C. \& Stephenson, A.G. (1993) Effects of soil-nitrogen on pollen production, pollen grain-size, and pollen performance in Cucurbita pepo (Cucurbitaceae). American Journal of Botany, 80, 763-768.

Lord, E. (1978) The development of cleistogamous and chasmogamous flowers in Lamium amplexicaule (Labiateae): an example of the heteroblastic inflorescence. Botanical Gazette, 140, 39-50.

Meier, C.L. \& Bowman, W.D. (2008) Links between plant litter chemistry, species diversity, and below-ground ecosystem function. Proceedings of the National Academy of Sciences of the United States of America, 105, 1978019785.

Milcu, A., Partsch, S., Langel, R. \& Scheu, S. (2006) The response of decomposers (earthworms, springtails and microorganisms) to variations in species and functional group diversity of plants. Oikos, 112, 513-524.

Moeller, D.A. (2004) Facilitative interactions among plants via shared pollinators. Ecology, 85, 3289-3301.

Muñoz, A.A., Celedon-Neghme, C., Cavieres, L.A. \& Arroyo, M.T.K. (2005) Bottom-up effects of nutrient availability on flower production, pollinator visitation, and seed output in a high-Andean shrub. Oecologia, 143, 126135 .

Nilsson, M.C., Wardle, D.A. \& Dahlberg, A. (1999) Effects of plant litter species composition and diversity on the boreal forest plant-soil system. Oikos, 86, 16-26.

Nilsson, M.C., Wardle, D.A. \& DeLuca, T.H. (2008) Belowground and aboveground consequences of interactions between live plant species mixtures and dead organic substrate mixtures. Oikos, 117, 439-449.

Ohashi, K. \& Yahara, T. (2001) Behavioural responses of pollinators to variation in floral display size and their influences on the evolution of floral traits. Cognitive Ecology of Pollination (eds L. Chittka \& J.D. Thomson), pp. 274296. Cambridge University Press, Cambridge.

Osborne, J.L., Awmack, C.S., Clark, S.J., Williams, I.H. \& Mills, V.C. (1997) Nectar and flower production in Vicia faba L (field bean) at ambient and elevated carbon dioxide. Apidologie, 28, 43-55.

Percival, M.S. (1961) Types of nectar in angiosperms. New Phytologist, 60, 235-281.

Petanidou, T., VanLaere, A.J. \& Smets, E. (1996) Change in floral nectar components from fresh to senescent flowers of Capparis spinosa (Capparidaceae), a nocturnally flowering Mediterranean shrub. Plant Systematics and Evolution, 199, 79-92.

Petanidou, T., Goethals, V. \& Smets, E. (1999) The effects of nutrient and water availability in the nectar production and nectary structure of the dominant Labiatae species of phrygana. Systematics and Geography of Plants, 68, 233244.

Pierre, J., Mesquida, J., Marilleau, R., Pham-Delegue, M.H. \& Renard, M. (1999) Nectar secretion in winter oilseed rape, Brassica napus - quantitative and qualitative variability among 71 genotypes. Plant Breeding, 118, 471476.

Potts, S.G., Vulliamy, B., Dafni, A., Ne'eman, G., O’Toole, C., Roberts, S. \& Willmer, P. (2003) Response of plant-pollinator communities to fire: changes in diversity, abundance and floral reward structure. Oikos, 101, 103-112. 
Potts, S.G., Vulliamy, B., Roberts, S., O’Toole, C., Dafni, A., Ne'eman, G. \& Willmer, P.G. (2004) Nectar resource diversity organises flower-visitor community structure. Entomologia Experimentalis Et Applicata, 113, 103107.

Potts, S.G., Biesmeijer, J.C., Kremen, C., Neumann, P., Schweiger, O. \& Kunin, W.E. (2010) Global pollinator declines: trends, impacts and drivers. Trends in Ecology \& Evolution, in press.

Poveda, K., Steffan-Dewenter, I., Scheu, S. \& Tscharntke, T. (2003) Effects of below- and above-ground herbivores on plant growth, flower visitation and seed set. Oecologia, 135, 601-605.

Poveda, K., Steffan-Dewenter, I., Scheu, S. \& Tscharntke, T. (2005) Floral trait expression and plant fitness in response to below- and aboveground plantanimal interactions. Perspectives in Plant Ecology Evolution and Systematics, 7, 77-83.

Proctor, M., Yeo, P. \& Lack, A. (1996) The Natural History of Pollination. Harper Collins Publishers, London, UK.

Pywell, R.F., Warman, E.A., Hulmes, L., Hulmes, S., Nuttall, P., Sparks, T.H., Critchley, C.N.R. \& Sherwood, A. (2006) Effectiveness of new agri-environment schemes in providing foraging resources for bumblebees in intensively farmed landscapes. Biological Conservation, 129, 192-206.

Quested, H.M. \& Eriksson, O. (2006) Litter species composition influences the performance of seedlings of grassland herbs. Functional Ecology, 20, 522532.

Quested, H.M., Callaghan, T.V. \& Press, M.C. (2003) Litter of hemiparasite Bartsia alpina enhances plant growth: evidence for a functional role in nutrient cycling. Oecologia, 135, 606-614.

R Development Core Team (2010) R: A Language and Environment for Statistical Computing Foundation for Statistical Computing. R Foundation for Statistical, Vienna, Austria.

Robertson, A.W., Mountjoy, C., Faulkner, B.E., Roberts, M.V. \& Macnair, M.R. (1999) Bumble bee selection of Mimulus guttatus flowers: the effects of pollen quality and reward depletion. Ecology, 80, 2594-2606.

Rusterholz, H.P. \& Erhardt, A. (1998) Effects of elevated CO2 on flowering phenology and nectar production of nectar plants important for butterflies of calcareous grasslands. Oecologia, 113, 341-349.

Schlesinger, W.H. (1997) Biogeochemistry: An Analysis of Global Change, 2nd edn. Academic Press, New York.

Steffan-Dewenter, I., Potts, S.G. \& Packer, L. (2005) Pollinator diversity and crop pollination services are at risk. Trends in Ecology \& Evolution, 20, 651652.

Temperton, V.M., Mwangi, P.N., Scherer-Lorenzen, M., Schmid, B. \& Buchmann, N. (2007) Positive interactions between nitrogen-fixing legumes and four different neighbouring species in a biodiversity experiment. Oecologia, 151, 190-205.

Torang, P., Ehrlen, J. \& Agren, J. (2006) Facilitation in an insect-pollinated herb with a floral display dimorphism. Ecology, 87, 2113-2117.

Trinsoutrot, I., Recous, S., Mary, B. \& Nicolardot, B. (2000) C and N fluxes of decomposing $13 \mathrm{C}$ and $15 \mathrm{~N}$ Brassica napus $\mathrm{L}$.: effects of residue composition and $\mathrm{N}$ content. Soil Biology and Biochemistry, 32, 1717-1730.
Truscott, A.M., Soulsby, C., Palmer, S.C.F., Newell, L. \& Hulme, P.E. (2006) The dispersal characteristics of the invasive plant Mimulus guttatus and the ecological signifiance of increased occurence of high-flow events. Journal of Ecology, 94, 1080-1091.

Wardle, D.A., Bardgett, R.D., Klironomos, J.N., Setälä, H., Van der Putten, W.H. \& Wall, D.H. (2004) Ecological linkages between aboveground and belowground biota. Science, 304, 1629-1633.

Waser, N.M. (1978) Competition for hummingbird pollination and sequential flowering in 2 colorado wildflowers. Ecology, 59, 934-944.

Wolfe, B.E., Husband, B.C. \& Klironomos, J.N. (2005) Effects of a belowground mutualism on an aboveground mutualism. Ecology Letters, 8, 218223.

Wykes, G.R. (1952) An investigation of the sugars present in the nectar of flowers of various species. New Phytologist, 51, 210-215.

Received 19 May 2010; accepted 4 January 2011

Handling Editor: Sedonia Sipes

\section{Supporting Information}

Additional Supporting Information may be found in the online version of this article:

Figure S1. Effects of litter on plant traits of M. guttatus, L. amplexicaule and M. sativa.

Figure S2. Effects of plant interaction on plant traits of M. guttatus, L. amplexicaule and M. sativa.

Figure S3. Effects of litter on nectar traits of M. guttatus, L. amplexicaule and M. sativa.

Figure S4. Effects of plant interaction on nectar traits of M. guttatus, L. amplexicaule and M. sativa.

As a service to our authors and readers, this journal provides supporting information supplied by the authors. Such materials may be re-organized for online delivery, but are not copy-edited or typeset. Technical support issues arising from supporting information (other than missing files) should be addressed to the authors. 